\title{
PLATFORM DIGITAL SEBAGAI ALTERNATIF BERTAHAN DI ERA PANDEMI COVID-19 BAGI PELAKU BISNIS PERTANIAN
}

\section{DIGITAL PLATFORM AS AN ALTERNATIVE TO SURVIVE IN THE ERA OF PANDEMIC COVID-19 FOR AGRICULTURAL BUSINESSES}

\author{
Damara Dinda Nirmalasari Zebua*, Lasmono Tri Sunaryanto \\ Universitas Kristen Satya Wacana, J1. Diponegoro No. 52-60, Salatiga, Jawa Tengah \\ *E-mail: damaradinda.zebua@uksw.edu \\ (Diterima 18-1-2021; Disetujui 26-1-2021)
}

\begin{abstract}
ABSTRAK
Salah satu pusat perbelanjaan sayur dan buah yang terkena dampak pandemi Covid-19 adalah Agro Store yang dikelola oleh Hortimart Agro Center. Penelitian ini bertujuan untuk: 1) mengetahui dampak pandemi Covid-19; 2) mengetahui penggunaan platform digital; dan 3) mengetahui kendala penjualan online. Penelitian ini adalah deskriptif kualitatif dengan metode analisis data menggunakan model analisis interaktif yang meliputi reduksi, penyajian data dan penarikan kesimpulan dengan bantuan alat analisis Atlas.ti 8 untuk pengkodingan data. Hasil penelitian menyimpulkan: 1) pandemi Covid-19 menyebabkan kegiatan operasional di Agro Store terpaksa ditutup selama empat bulan yang berimbas pada menurunnya omset penjualan; 2) platform digital Whatsapp merupakan alternatif platform bagi Agro Store untuk menjual produk sayur dan buah secara online; dan 3) kendala secara internal adalah kurangnya sumberdaya manusia dan transportasi, sedangkan kendala eksternal adalah komplain dari konsumen. Implikasi penelitian ini bagi Agro Store yaitu sebagai pengingat sekaligus pematik untuk tetap konsisten menggunakan platform digital sebagai media pemasaran produk sayur dan buah secara online sebagai peluang untuk memperluas pasar dan meningkatkan omset penjualan.
\end{abstract}

Kata kunci: pandemi Covid-19, pemasaran online, whatsapp, pusat perbelanjaan

\section{ABSTRACT}

One of the vegetable and fruit shopping centers that affected by the Covid-19 pandemic is the Agro Store which is managed by the Hortimart Agro Center. This study aims to know: 1) the impact of the Covid-19 pandemic; 2) the use of the digital platform; and 3) the advantages of using digital platform. This is a descriptive qualitative research by using an interactive analysis model includes reduction, data presentation and conclusion drawing that used Altas.ti 8 as an analysis tool for data coding. The results of the study concludes: 1) the Covid-19 pandemic caused operational activities at the Agro Store to be closed for approximately four months; 2) the Whatsapp digital platform is an alternative platform for Agro Store to sell vegetable and fruit products online; and 3) internal constraints are the lack of human resources and transportation, while external constraints are complaints from customers. The implication of this research for Agro Store is a reminder and also a trigger to consistent use the digital platform as a marketing media of selling vegetable and fruit products online as an opportunity to expand the market and increase sales turnover.

Keywords: Covid-19 pandemic, online marketing, whatsapp, shopping centers

\section{PENDAHULUAN}

Virus corona atau yang lebih

dikenal dengan Covid-19 sejak akhir
Agustus 2019 telah melanda warga kota

Wuhan di China, hingga pada awal Maret

2020, virus tersebut melanda negara 
Indonesia. Dalam menyikapi hal ini, pemerintah tidak gegabah untuk mengambil langkah dan tidak langsung menerapkan kebijakan lockdown seperti negara lain, pemerintah masih berpikir kebijakan yang paling tepat untuk diberlakukan di Indonesia. Hal ini dikarenakan kebijakan lockdown dapat memberikan dampak negatif terutama terhadap perekonomian negara. Lockdown akan memutus akses sementara antara tempat satu dengan yang lainnya. Hal ini sejalan dengan penelitian Yunus \& Rezki (2020) yang menyatakan bahwa kebijakan lockdown dapat membuat perekonomian Indonesia merosot yang ditandai dengan laju pertumbuhan ekonomi yang lambat.

Pemerintah telah mempertimbangkan hal tersebut, sehingga pemerintah mengambil langkah untuk menghimbau agar seluruh masyarakat tetap tinggal di rumah dan mengurangi mobilitasnya untuk memperlambat penyebaran Covid19. Langkah utama yang diambil dan diterapkan pemerintah adalah pembatasan sosial (social distancing) seperti bekerja dari rumah, belajar dari rumah dan beribadah dari rumah (Humas, 2020a). Hal tersebut disusul dengan informasi yang disampaikan oleh Presiden Republik Indonesia, Joko Widodo yang menyatakan bahwa pemerintah telah menetapkan virus tersebut sebagai jenis penyakit dan faktor risiko yang mengakibatkan kedaruratan kesehatan masyarakat. Oleh karena itu, pemerintah lalu mengambil langkah untuk mengatasinya dengan menetapkan kebijakan pembatasan sosial berskala besar (PSBB). Kebijakan ini diambil atas dasar hukum yang mengacu pada Undang-undang Nomor 6 Tahun 2018 tentang Kekarantinaan Kesehatan (Humas, 2020b). Kebijakan ini juga membuat sejumlah pemerintah di tingkat daerah untuk mengambil kebijakan menutup sementara semua pusat perbelanjaan dan wisata untuk menghindari bertemunya banyak orang pada satu waktu dan satu tempat yang sama.

Kebijakan yang diberlakukan oleh pemerintah di tingkat daerah, ternyata membawa dampak yang signifikan bagi para pelaku usaha yang ada di dalamnya. Banyak pelaku usaha yang mengalami penurunan omset dikarenakan berkurangnya jumlah konsumen yang berkunjung dan melakukan pembelian ke tempat usahanya. Hal ini sesuai dengan penelitian Hardilawati (2020) yang menemukan bahwa di era pandemi Covid-19, sebagian besar penjualan 
secara langsung mengalami penurunan omset. Taufik \& Ayuningtyas (2020) menambahkan, kebijakan tersebut tidak hanya berdampak bagi pelaku usaha, melainkan juga bagi konsumen dan pemilik properti. Konsumen dibatasi mobilitasnya sehingga tidak dapat melakukan pembelian langsung pada toko/outlet tertentu atau tidak dapat menikmati berbagai keindahan wisata yang ditawarkan oleh jasa tertentu. Pemilik properti mengalami penurunan omset dikarenakan banyak toko/outlet yang menghentikan sementara sewa ruangan/space yang disediakan oleh pemilik properti.

Di sisi lain, penurunan omset yang dialami oleh setiap pelaku usaha juga berdampak pada kehidupan karyawan yang sehari-harinya mengandalkan pendapatan dari tempat usaha tersebut. Tidak sedikit karyawan yang harus dirumahkan karena pelaku usaha mengambil sikap untuk mengurangi jumlah karyawannya sehingga terpaksa melakukan pemutusan hubungan kerja terhadap beberapa karyawan. Hal ini didukung oleh Pakpahan (2020) dalam penelitiannya, yang mengungkapkan bahwa adanya kebijakan social distancing yang kemudian berubah menjadi physical distancing memberi dampak bagi perusahaan berupa penurunan kinerja sehingga menyebabkan efek domino berupa pemutusan hubungan kerja. Perusahaan yang mengalami dampak lebih signifikan berupa kebangkrutan justru langsung memutuskan untuk menutup usahanya. Kondisi tersebut secara tidak langsung membuat pelaku usaha tidak mempunyai pilihan lain untuk mengatasi kerugian kecuali dengan melakukan pemutusan hubungan kerja. Anwar (2020) menambahkan, pemutusan hubungan kerja dilakukan oleh perusahaan dengan tujuan untuk menekan biaya operasional secara besar-besaran.

Akan tetapi, bagi beberapa jenis usaha tertentu yang dapat dijalankan tanpa harus ada interaksi langsung antara pelaku usaha dan konsumen, masih dapat bertahan di tengah pandemi Covid-19. Beberapa diantaranya yaitu jenis usaha di bidang makanan dan minuman, kebutuhan bahan pokok dan produk kesehatan. Alternatif bertahan yang dapat dilakukan oleh pelaku usaha adalah dengan memanfaatkan berbagai macam platform digital yang tersedia dan dikenal dengan sistem e-commerce. E-commerce memungkinkan pelaku usaha dan konsumen melakukan transaksi bisnis tanpa bertatap muka langsung, melainkan 
cukup menggunakan media elektronik. Awali \& Rohmah (2020) membenarkan bahwa e-commerce memungkinan pelaku usaha untuk mendistribusikan produknya kepada konsumen. Selain itu, hal tersebut juga berguna untuk mendorong pelaku usaha agar melek teknologi sekaligus beradaptasi dengan norma baru yaitu penggunaan teknologi dalam menjalankan usaha yang diperkirakan akan terus berlangsung pasca Covid-19.

Agro Store merupakan salah satu pusat perbelanjaan sayur dan buah yang terkena dampak dari adanya pandemi Covid-19. Tepat dua minggu setelah Covid-19 masuk ke Indonesia, disusul dengan adanya kebijakan PSBB, maka Agro Store terpaksa untuk menutup sementara toko/outletnya selama kurang lebih 4 bulan. Akan tetapi, tutupnya toko/outlet tersebut tidak sampai membuat pelaku usaha melakukan pemutusan hubungan kerja terhadap karyawannya. Hal ini dikarenakan Agro Store langsung beralih menggunakan platform digital sebagai media penjualan sayur dan buah. Berbeda dengan penelitian-penelitian sebelumnya yang dilakukan terhadap berbagai pelaku usaha yang menggunakan platform digital setelah terdampak pandemi Covid-19, Agro Store sudah memiliki platform digital seperti whatsapp dan instagram jauh sebelum adanya pandemi Covid-19, tetapi pada pemanfaatannya sebagai media penjualan sayur dan buah belum digunakan secara optimal. Platform digital tersebut baru mulai dioptimalkan penggunaannya sejak Agro Store menutup toko/outletnya. Oleh karena itu, peneliti tertarik untuk mengetahui: 1) dampak pandemi Covid-19 terhadap Agro Store; 2) penggunaan platform digital oleh Agro Store; dan 3) kendala penjualan online yang dihadapi oleh Agro Store.

\section{METODE PENELITIAN}

Jenis penelitian yang digunakan adalah deskriptif kualitatif dengan metode wawancara mendalam (in-depth interview) menggunakan panduan wawancara kepada partisipan, yaitu dua orang karyawan bagian penjualan Agro Store sebagai pelaksana kegiatan penjualan sayur dan buah menggunakan platform digital, serta key informant yaitu Kepala Bagian Penjualan (KaBag Penjualan) Agro Store yang turut membantu partisipan dalam melaksanakan kegiatan penjualan. Kegiatan wawancara mendalam dilaksanakan selama bulan Juli hingga Oktober 2020 di toko/outlet Agro Store 
yang beralamat di Jalan Gatot Subroto No. 55, Bawen, Kabupaten Semarang, Jawa Tengah. Keabsahan data diuji dengan menggunakan metode triangulasi sumber dan waktu. Analisa data menggunakan model analisis interaktif yang dikemukakan oleh Miles, Huberman, \& Saldana (2014), meliputi reduksi data, penyajian data dan penarikan kesimpulan. Kesimpulan akan diverifikasi oleh peneliti selama penelitian berlangsung guna memperoleh kebenaran tentang data dan informasi. Alat analisis Atlas.ti 8 digunakan sebagai alat bantu dalam membuat pengkodingan data.

\section{HASIL DAN PEMBAHASAN}

\section{Dampak Pandemi Covid-19}

Pandemi Covid-19 seketika mengubah seluruh rutinitas setiap individu, kelompok, organisasi maupun korporasi. Dalam waktu kurang lebih dua minggu, semua fasilitas umum, pusat perbelanjaan serta tempat-tempat lain yang dapat mengundang massa untuk berkumpul telah ditutup. Bagi salah satu pusat perbelanjaan sayur dan buah yang ada di Jawa Tengah yaitu Agro Store, hal ini tentunya sangat berimbas pada omset penjualan yang diperoleh, dimana jumlah konsumen dan pendapatan berkurang, sementara pengeluaran bertambah. Hal ini diungkapkan oleh satu salah partisipan bahwa:

"Pas Covid bener-bener gimana ya,
ngefek banget sih, soalnya langsung
seketika itu konsumen pada berkurang.
Konsumen berkurang, jadi pendapatan
pun makin berkurang, biaya
bertambah. Jadi sebisa mungkin, kita
harus bisa gimana ya nyari cara buat
tetep sayuran atau buahnya yang di
kebun itu nggak sia-sia gitu".

Tidak hanya itu, Agro Store pun terpaksa langsung menutup total tokonya. Hal ini diungkapkan oleh partisipan lainnya:

"He'em, total, semua divisi tutup
total".

Keterangan ini juga dibenarkan oleh key informant selaku KaBag Penjualan Agro Store yang mengungkapkan bahwa pandemi ini membawa perubahan yang sangat signifikan sekali.
"Ya perbedaannya sangat signifikan sekali. Bukan cuma Hortimart, saya yakin sekali perusahaan di seluruh dunia, pasti juga mengalami istilahnya kemunduran atau kerugian, karena yang harusnya mungkin dari pabrik garmen kirim ke luar negeri, tapi ndak bisa kirim.Untuk Hortimart pun menjadi salah satu perusahaan yang merasakan akibat dari pandemi ini. Jadi, apa ya, jadi Hortimart tetap harus jalan, karyawannya tetap ada, cuma tidak bisa mendapatkan penghasilan. Jadi antara penghasilan dan pengeluaran, masih banyak dipengeluarannya, apalagi ketika tutup total kan pendapatannya nggak ada sama sekali, jadi kayak listrik kan 
masih jalan, apa-apanya masih jalan sетиа".

Selain berimbas pada tutupnya operasional toko, pandemi Covid-19 juga berimbas pada gaji karyawan, jumlah pengunjung dan omset penjualan, seperti yang dapat dilihat pada Tabel 1.

Tabel 1. Dampak Pandemi Covid-19

\begin{tabular}{lcc}
\hline \multicolumn{1}{c}{ Kategori } & $\begin{array}{c}\text { Sebelum } \\
\text { pandemi } \\
\text { (per bulan) }\end{array}$ & $\begin{array}{c}\text { Era pandemi } \\
\text { (per bulan) }\end{array}$ \\
\hline $\begin{array}{l}\text { Gaji } \\
\text { karyawan }\end{array}$ & $100 \%$ & $50 \%$ \\
$\begin{array}{l}\text { Jumlah } \\
\text { pengunjung }\end{array}$ & $>4.000$ & $<2.000$ \\
$\begin{array}{l}\text { Omset } \\
\text { penjualan }\end{array}$ & 400 juta & 200 juta \\
\hline Sumber: Analisis Data Primer (2021) &
\end{tabular}

Pemotongan gaji karyawan terpaksa dilakukan karena terjadinya penurunan omset, sementara kebutuhan operasional lainnya tetap harus dibayarkan. Hal tersebut menjadi keputusan dari owner Agro Store agar tetap bisa mempertahankan usahanya di tengah pandemi Covid-19. KaBag Agro Store menyebutkan beberapa detail kewajiban yang tetap harus dibayarkan walau toko sedang tidak beroperasi.

"Paling digajinya, kemarin sih keputusan dari pemilik itu sih 50\% dari gaji normal. Sini kan pengeluarannya juga banyak, untuk menggaji karyawan, untuk membayar listrik, membayar air, semuanya kan harus tetap dibayarkan gitu, karena walaupun sini tutup itu, kemarin itu tetap karyawan yang dirumahkan tetap digaji juga".
Di sisi lain, penurunan jumlah pengunjung disebabkan karena tidak adanya kunjungan-kunjungan dari berbagai instansi seperti dinas, sekolah atau universitas, dan juga rombongan pariwisata. Selama ini, tidak bisa dipungkiri bahwa kunjungan dari instansi dan rombongan pariwisata menjadi salah satu cara untuk mendatangkan banyak konsumen bagi Agro Store dan seluruh divisi lainnya. Hal ini disampaikan oleh partisipan yang mengeluhkan bahwa tidak adanya kunjungan membuat Agro Store sepi.

"Biasanya sini kan ada itu to, kunjungan-kunjungan, nah itu dari kunjungan-kunjungan itu sih".

$$
\text { Partisipan lainnya juga }
$$
mengungkapkan hal yang sama bahwa jumlah konsumen sebelum pandemi sangat ramai sekali dikarenakan sering dapat kunjungan-kunjungan.

"Kalo dari jumlah konsumen sebelum pandemi memang serame itu ya, soalnya kan ada kunjungan yang rombongan bis dari sekolah atau dari keluarga atau apa kan banyak".

Hal-hal tersebut menjadi penyebab menurunnya omset penjualan Agro Store. Penurunan omset yang dialami sangat drastis hingga $50 \%$, akibatnya owner dan seluruh manajer harus mencari cara yang tepat agar dapat terus bertahan selama pandemi Covid-19 berlangsung. 
Hadiwardoyo (2020) mengungkapkan bahwa tiap usaha akan mengalami kerugian rill yang berbeda-beda dan tetap mengeluarkan biaya rutin seperti gaji staf, pembayaran kepada supplier dan lain sebagainya.

\section{Penggunaan Platform Digital}

Menyikapi adanya dampak pandemi Covid-19, Agro Store berusaha menemukan alternatif lain agar tetap dapat berjualan sayur dan buah sehingga tidak mengalami kerugian yang berkelanjutan. Alternatif yang dilakukan yaitu dengan memanfaatkan platform digital Instagram dan Whatsapp untuk berjualan secara online dan produk akan dikirimkan ke rumah konsumen. Langkah ini diambil dua minggu setelah operasional toko ditutup. Partisipan menyampaikan bahwa dengan berjualan online sangat membantu karena toko tetap dapat memperoleh pendapatan walau diawal menjalankan penjualan secara online sempat merasa kewalahan.

"Mulai 23 Maret. Online berjalan ya, waktu awal-awal sih bener-bener tekanan banget, soalnya harus menerima pesanan dulu. Menerima pesanan, terus ngerekap, habis ngerekap nanti nyiapin dulu, setelah nyiapin, nanti di kasir dibuatin nota, habis dibuatin nota, nanti diurutin, urutannya. Ya pokoknya, intinya bener-bener ribet gitu, pas awal-awal bener-bener kita sangat menguras tenaga. Habis itu pas awal-awal pun armada masih satu, dan orderannya banyak, sampai malem itu pulangnya".

Partisipan menambahkan, promosi dilakukan melalui Instagram dan Whatsapp, kemudian juga menawarkan kepada beberapa langganan tetap yang sudah sering belanja sayur dan buah ke Agro Store. Belanja sayur dan buah via platform digital bebas dari biaya pengiriman, tetapi konsumen akan dikenakan minimal order jika ingin berbelanja. Minimal order yang diberlakukan tergantung dari wilayah tempat tinggal konsumen.

"Ini baru lewat via WA sama
instagram. Sini kan ada sie inventaris,
nah di situ kan banyak kontak WAnya
konsumen. Nah langsung disiaran,
gimana ya, langsung disiaran WA gitu
lho, bahwasannya kasih pengumuman
"sekarang Hortimart sedang tutup,
dialihkan ke delivery online. Terus
kalo mau pesen, bisa datanya ini aja,
ada batas minimal juga, nanti free
ongkir". Untuk wilayah Semarang
kota minimal 150, Banyumanik gitu,
sama Salatiga. Kalo yang Ambarawa
100 ribu, untuk yang Semarang Barat
sama Semarang Timur itu minimal
$300 "$.

Partisipan lainnya menambahkan bahwa awal Agro Store membagikan informasi untuk melayani belanja online, antusias konsumen sudah terlihat dari respon untuk membalas pesan dan dilanjutkan dengan pemesanan. Konsumen terbanyak yang melakukan 
pembelanjaan via platform digital adalah

konsumen dari Semarang.

"Instagram sama WAnya HP inven itu sih mbak, yang utama. Yang waktu itu diberitakan pertama itu di IG dulu, setelahnya langsung di WAnya itu sih. Pertama itu sih penasaran, jadi kayak tanya-tanya gitu, tapi lama-lama banyak yang tertarik sih mbak, jadi ikut, mau minta ngirim sayur ke rumah. Kalo yang pertama itu ke area Semarang sih mbak, soalnya konsumen kan kebanyakan di Semarang, gitu".

Key informant yang merupakan KaBag Penjualan Agro Store menjelaskan bahwa salah satu alasan memilih menjual sayur dan buah secara online yaitu karena produk buah dan sayur bukanlah produk yang dapat disimpan lama, melainkan produk yang harus segera didistribusikan ke konsumen dan tidak dapat dihentikan produksinya. Oleh karena itu, Manajer Operasional Pemasaran memberi mandat kepada KaBag Agro Store untuk segera melakukan penjualan secara online. KaBag Agro Store menambahkan, penjualan online sebelumnya sudah ada tetapi hanya untuk memenuhi beberapa permintaan langganan tetap yang tidak bisa berbelanja langsung ke toko. Kemudian, sejak pandemi ini, penjualan online dibuka kepada semua masyarakat Kota Semarang dan sekitarnya.

"Manajer Operasional Pemasaran ngasih corenya, divisi ngembangin. Pandemi ini, ada keputusan bahwa
Hortimart harus ditutup karena memang instruksi dari pemerintah, nah akhirnya karena produknya yang dijual adalah produk-produk yang tidak tahan lama, maksudnya tidak seperti baju kan yang bisa disimpan lama. Tapi kan produknya Hortimart itu kan buah dan sayur yang panennya tidak bisa dihentikan hanya karena pandemi. Jadi, karena alasan harus tutup akhirnya kami menggencarkan Hortimart online itu sendiri. Jadi yang biasanya memang ada, cuma sedikitsedikit dan bukan penjualan utamanya, jadi penjualan tambahan aja untuk memenuhi konsumen yang nggak bisa datang ke sini. Nah sekarang benarbenar digencarkan untuk mengurangi apa ya, memang kesempatannya ada karena memang banyak orang kan nggak bisa datang ke sini sendiri, terus maksudnya konsumen sendiri memberikan kesempatan untuk kirim ke rumah, kemudian untuk mengurangi orang agar tidak terlalu banyak yang datang ke sini, gitu".

Key informant menambahkan, diterapkannya penjualan online memang belum mampu mengembalikan omset penjualan seperti semula saat pandemi belum berlangsung, tetapi setidaknya penjualan online mampu menutup biaya operasional yang hingga saat ini masih harus dibayarkan oleh perusahaan. Bisa dikatakan jika pendapatan dan pemasukan berimbang sehingga Agro Store dapat bertahan di era pandemi, sekaligus sebagai penyokong bagi divisi lainnya.

\footnotetext{
"Kalo profit sih mungkin belum, tapi mengurangi tingkat kerugian dari yang kemarin mungkin lebih ke BEP, jadi lebih ke istilahnya bak bok, atau
} 
balance gitu antara pengeluaran dan pemasukan, yang penting jalan aja, omsetnya nggak usah dipikirin dulu yang penting bisa bayar karyawan. Strategi bertahannya manajer operasional pemasaran kayak gitu”.

Antusias konsumen untuk berbelanja sayur dan buah secara online cukup tinggi, dapat dilihat dari rata-rata jumlah kiriman yang diantarkan per harinya. Selama berjualan online, pengantaran dilakukan tiga kali dalam seminggu. Dalam satu kali pengantaran, biasanya bisa mencapai 50 nota atau sama artinya dengan 50 alamat, mulai dari konsumen di Semarang, Salatiga dan Ambawara.

\begin{abstract}
"Yang pesen banyak, antusiasnya pun banyak. Pas online, paling banyak 50 nota lah. 50 nota berarti 50 pengiriman kan, dengan rata-rata taruhlah minimal belanja kan 150, tapi rata-rata Semarang. Jadi yang Salatiga, Ambarawa, itu jarang banget, cuman itungan jari. Semarang kan 250, itu kalo dirata-rata berapa".
\end{abstract}

Setelah operasional toko tutup selama kurang lebih 4 bulan, akhirnya toko dibuka kembali. Tentunya sudah mengikuti standar protokol kesehatan dan seizin Dinas Pariwisata. Dibukanya toko ini ternyata juga mendapat respon positif dari konsumen, karena beberapa konsumen akhirnya sudah dapat berbelanja langsung ke toko. Ada penurunan jumlah pesenan online sejak toko dibuka, tetapi itu karena konsumen memilih untuk berbelanja langsung. Meski begitu, penjualan online tetap dilayani. Akan tetapi yang tadinya pengantaran tiga kali dalam seminggu, saat ini menjadi dua kali dalam seminggu. Selain itu, jumlah pemesan juga dibatasi 20-30 alamat saja, dikarenakan keterbatasan transportasi pengantaran dan juga untuk mencegah agar di toko tidak kekurangan karyawan.

"Kalo sekarang buka, onlinenya dialihkan ke Selasa sama Kamis. Tiap ada kiriman online dibatasi, jadi untuk hari Selasa misal dibatasinya sekitar 20 atau 30 konsumen, gitu. Jadi nggak seribet waktu yang awal-awal banget itu sih mbak. Kalo yang di toko, 7 orang total. Jadi 4 cowo, sama 3 cewe. Tapi kan kalo pas pandemi itu kan yang dikirim setiap Senin, Rabu sama Jumat, setelah buka kan cuman Selasa Kamis, gitu sih. Mungkin hari itu dipindah karena sudah buka dan membatasi ya, biar nggak terlalu sering ke luar, di sini kan juga kekurangan orang".

Walaupun toko sudah beroperasional kembali, partisipan menyadari bahwa pendapatan penjualan online masih jauh lebih tinggi dibandingkan dengan di toko, hal ini dikarenakan penjualan online menerapkan minimal order dan dianggap lebih praktis oleh konsumen.
"Yang online itu lebih ke misal ya, barangnya segini, kalo sebelumnya pas offline misalnya pendapatannya 2 juta aja, kalo online bisa lebih dari itu. Soalnya kan ada batas minimalnya itu. 
Jadi ada gimana ya, kayak ada targetannya lah gitu”.

"Orang yang biasanya keluar pergi ke pasar atau ke supermarket, mereka kan jadi lebih enak. Tinggal di rumah aja, pesen sayur, bisa datang. Apalagi waktu itu dari pemerintah kan memang diharuskan di rumah mbak, nggak boleh keluar, jadi lebih efektif sih mbak.

Partisipan lainnya menambahkan bahwa dibukanya toko dan masih berlangsungnya penjualan online justru memberikan dampak yang baik karena pendapatannya bisa menjadi dua kali lipat, jika sebelumnya hanya menunggu konsumen datang saja, saat ini juga bisa mengirimkan langsung ke konsumen.

\begin{abstract}
"Kalo dampaknya buat Horti sih ada plus minusnya, nah plusnya kalo setelah buka gini kan pendapatannya jadi dua kali lipat kan, yang tadinya jualannya cuma di toko nunggu orang dateng, kan sekarang ada yang dikirim ke luar. Kalo minusnya sih, mungkin jadi kekurangan orang ya di toko, soalnya kan temen jadi ada yang ke luar. Di sini paling tinggal dua atau tiga orang, gitu sih".
\end{abstract}

Key informant juga melihat hal yang sama bahwa penjualan online memiliki prospek yang baik untuk ke depannya, termasuk untuk memperluas pasar, seperti cita-cita owner Agro Store yang ingin jika suatu saat Agro Store bisa ada di berbagai kota di Indonesia.

"Karena dilihat, apa ya, kesempatan onlinenya itu bagus loh sebenarnya, makanya kemarin ternyata banyak banget kan yang pesen online. Yaudah kenapa ini nggak dijalanin terus, gitu.
Kalo ownernya Hortimart sendiri, pengennya suatu saat Hortimart itu kayak bisa dibuat franchise gitu, jadi bisa melebar kemana-mana, kayak Indomaret, Alfamart, karena konsumennya Hortimart sebenarnya bisa sampai luar kota juga, cuma kita luar kota itu belum ada Hortimart, pengennya Hortimart memenuhi kebutuhan konsumen sayur dan buah di seluruh Indonesia, karena ownernya sendiri itu kan sangat mencintai pertanian, terus sama visi misinya lebih ke buah-buah dan sayur lokal, makanya sini ndak ada buah impor, ndak boleh".

Selain itu, key informant menyampaikan, bahwa untuk menjaga rasa aman bagi konsumen yang berbelanja secara online, karyawan yang mengantar produk sudah dibekali dengan alat pelindung diri (APD) lengkap dan juga selalu mengenakan hand sanitizer terlebih dahulu sebelum menyerahkan produk kepada konsumen.

"Biasanya sih persiapannya lebih ke packaging agar sampai di konsumen dengan baik, persiapannya juga ditransportasinya, personil juga. Jadi membawa APD ketika kirim, kadangkadang kan ada konsumen yang takut ketemu orang asing walaupun sering ketemu Hortimart kan tetap dianggapnya sebagai orang asing. Jadi tetap menggunakan masker, menggunakan sarung tangan, menggunakan face shield, terus membawa handsanitizer.

Tindakan Agro Store untuk menggunakan platform digital Instagram sebagai wadah promosi dan Whatsapp sebagai wadah untuk berkomunikasi 
langsung dengan konsumen, ternyata membuahkan hasil yang baik. Dengan penggunaan kedua platform tersebut, Agro Store mampu mempertahankan usahanya dan membiayai seluruh kebutuhan operasional setiap bulannya hingga saat ini. Temuan ini sesuai dengan penelitian Hardilawati (2020) yang mengungkapkan bahwa pelaku usaha mampu bertahan di era pandemi jika dapat menyesuaikan diri terutama dalam memilih beberapa strategi pemasaran untuk bertahan, salah satunya dengan memanfaatkan jejaring sosial. Taufik \& Ayuningtyas (2020) menambahkan bahwa beberapa bidang usaha dapat mengalami kendala dalam pengembangannya bahkan penurunan selama masa pandemi Covid-19 jika tetap bertahan pada kunjungan langsung dari konsumen.

\section{Kendala Penjualan Online}

Dalam pelaksanaan penjualan online yang dilakukan Agro Store melalui penggunaan platform digital, ternyata tidak mulus begitu saja. Pada realisasinya, masih ditemukan beberapa kendala baik dari internal yaitu karyawan dan armada transportasi maupun eksternal yaitu konsumen. Kendala dari sisi internal dialami terutama setelah operasional toko dibuka. Karyawan seringkali merasa kewalahan ketika tiba jadwal pengiriman, hal ini dikarenakan jumlah karyawan Agro Store yang terbatas.

"Iya, di sini itu dibagi, ada yang khusus untuk ngirim, ada yang khusus untuk bagian admin".

Key informant menambahkan, kendala ini dikhawatirkan dapat berimbas pada tidak maksimalnya pelayanan yang diberikan kepada pengunjung toko, terutama saat ramai pembeli.

"Iya, sopirnya dari sini juga. Jadi sekali dikirim itu yang ke luar sudah 4 orang, jadi yang di sini tinggal 3 orang, kadang kalo pas posisinya rame mungkin agak kendala dibagian pelayanan, jadi tidak bisa maksimal. Karena sini kan memang utama Hortimart juga mengutamakan pelanggan maksudnya".

Selain itu, kendala internal lainnya adalah kurangnya armada atau mobil yang digunakan sebagai alat transportasi untuk mengantarkan produk ke konsumen. Ditambah lagi, jika ada konsumen yang meminta agar produknya bisa sampai pada jam yang dikehendaki, ini terkadang sulit untuk dapat dipenuhi.
"Kendalanya sih, karena konsumennya banyak, kalo sekali kirim di Semarang itu kan satu, kemarin kan awalnya punya dua mobil, eh awalnya pertamanya punya satu mobil, ternyata permintaan online meningkat lagi lalu ditambah dua mobil, kemudian meningkat lagi jadi tiga mobil. Lha tiga mobil ini, tetap ada kendala- 
kendala, maksudnya ketika ada konsumen-konsumen yang pengen sampainya pagi atau sampainya siang, kadang-kadang kan kalo kirim ke Semarang kan dimulai dari yang terdekat dulu”.

Kendala eksternal yang dialami yaitu adanya komplain dari konsumen dan beberapa barang yang dikembalikan (diretur). Penuturan salah satu partisipan, biasanya konsumen komplain jika produk yang dikirim tidak sesuai harapan, terkadang juga karena produk buah yang dikirim setelah beberapa hari di rumah, tetap tidak matang juga.

"Kendalanya itu ya mungkin kalo
misalnya barangnya yang dipesen
konsumen kurang bagus, komplainan
gitu. Misalnya komplain, pisangnya.
"Pisangnya kok nggak mateng-
mateng?" atau nggak "bonyok
semua" atau gini gini gini, atau ada
lagi tempatnya yang deket pantai, kan
panas ya kan, ke sana kan
kemungkinan besar kan sayurnya
mungkin layu atau gimana, dari
kondisi itu. Dari kondisi tempatnya
lah".
Partisipan menambahkan, pengembalian barang juga pernah terjadi, misalnya jika produk dianggap konsumen kurang bagus atau mudah busuk. Respon yang dilakukan oleh Agro Store yaitu berupa penukaran produk atau bisa juga langsung dipotong dari total nominal yang seharusnya dibayarkan.

\footnotetext{
"Karena mungkin kebetulan panenannya lagi kurang bagus atau ndak sayur kebetulan panennya kurang bagus, jadi sampai sananya itu
}

mudah busuk. Ada buktinya juga kenapa kok jelek, jeleknya itu mungkin ada yang busuk atau apalah gitu. Nanti difotoin. Kalo dari komplain itu biasanya, kalo nggak ditukerin yang baru, itu nanti dipotong dari transaksinya".

Salah satu penyebab kesegaran sayur selama perjalanan kurang terjaga yang mengakibatkan adanya komplain dari konsumen yaitu armada yang digunakan masih berupa mobil biasa, belum dilengkapi dengan mesin pendingin untuk menjaga suhu produk tetap stabil, seperti ungkapan key informant berikut.

"Iya, masih mobil biasa. Jadi salah
satu kendalanya itu, jadi kualitas
produknya kadang-kadang ketika
sampai di Horti, e dikonsumen, sudah
tidak sebagus waktu berangkat".

Menariknya, walau konsumen ada yang pernah komplain karena pesanannya tidak sesuai harapan, konsumen ini masih tetap kembali melakukan pembelian sayur dan buah, bahkan diantaranya turut merekomendasikan kepada temantemannya yang lain, seperti penuturan partisipan berikut.

"Mereka rata-rata kembali kok mbak, walaupun tetep komplain, tapi tetep beli lagi, beli lagi. Mungkin udah cocok kali ya mbak, atau karena bisa dianter ke rumah itu mungkin, jadi nggak ribet harus ke luar, seperti itu mungkin alasannya, atau mungkin karena mereka lebih suka sayuran organik daripada yang di luar kan kadang ada yang disemprot, ada yang apa gitu, mungkin mbak.. Tapi rata- 
rata balik lagi, belanja lagi, belanja lagi”.

"Pertama mereka alasannya, pernah saya tanyain juga, waktu itu ada konsumen dari Solo, "kan dari sana juga ada Bu yang jual, kenapa harus ke Hortimart?" Katanya, direkomendasiin teman, terus yang kedua, emang pernah ngerasain beberapa kali buah dan sayur sini, dan cocok. Jadi kayak kembali lagi belanjanya ke sini, gitu. Jadi kayak dari mulut ke mulut gitu loh mbak, "eh belanja di Hortimart itu lho..", terus penasaran kan, dateng ke sini, lihat langsung".

Kembali pada hal lain yang juga menjadi kendala adalah ketika ada konsumen yang sulit ditagih padahal sudah waktunya melakukan pembayaran. Keunikan mekanisme pembayaran pada Agro Store yaitu produk diterima dahulu oleh konsumen, lalu konsumen diberikan kesempatan hingga maksimal tiga hari untuk melakukan transaksi pembayaran.

Mekanisme ini dilakukan untuk mengantisipasi jika produk yang dipesan tidak tersedia, sehingga pihak Agro Store tidak perlu melakukan pengembalian sejumlah uang kepada konsumen.

"Sering, kejadian kayak konsumen yang lupa, lupa menyampaikan kalo beliau sudah transfer, tapi di sini sebenarnya sudah masuk, tapi memang karena kekurangan info biasanya kan ada bukti transfernya itu, jadi bukti transfernya hilang, atau ndak beliau kelupaan sampai nggak transfer, jadi harus diingatkan lagi. Terus ada juga sing, ada customer yang kadangkadang agak susah ditagih gitu”.
"Soalnya kita nanggung, malah yang utang gitu lho kayaknya, maksudnya kan takutnya barangnya sini ndak pasti ada, jadinya gimana ya, mengurangilah, meminimalisir, misal ada yang harus bayar dulu, itu kan berarti kan udah pasti ada to. Kalo yang ini, belum pasti, jadi takutnya nanti kita yang utang ke sana, utang ke konsumen, gitu. Jadi kita malah ngembaliin, malah ribet lagi nanti".

Secara keseluruhan, kendala yang dihadapi oleh Agro Store dapat diatasi, terutama yang berkaitan dengan komplain dari konsumen. Standar Operasional Prosedur (SOP) yang diterapkan untuk menangani komplain juga sangat baik. Komplain konsumen ditanggapi dengan permintaan maaf terlebih dahulu, kemudian dilanjutkan dengan memberikan penjelasan, lalu menawarkan solusi kepada konsumen, seperti penjelasan partisipan berikut.

\footnotetext{
"Ngatasin komplainnya ya mungkin yang pertama, permintaan maafnya dulu, terus ngasih penjelasan, habis itu terimakasih. Gitu sih, udah. Ya yang pastinya itu sih ngasih penjelasan itu. Atau kalo ndak diganti, diretur, ya dikembalikan, gitu'.
}

Hal tersebut dilakukan juga sebagai salah satu upaya untuk dapat mempertahankan loyalitas konsumen sehingga dapat terus melakukan pembelian ulang dan merekomendasikan Agro Store kepada orang lain. Sanjayawati (2019) dalam penelitiannya membuktikan bahwa penanganan 
komplain berpengaruh signifikan terhadap kepuasan pelanggan yang dianggap sebagai wujud pelayanan terbaik sehingga mampu membuat pelanggan loyal. Di sisi lain, Artanti \& Adinugraha (2020) mengungkapkan bahwa strategi pemasaran dari mulut ke mulut berhasil mempengaruhi keputusan pembelian seseorang dikarenakan telah mendengar cerita langsung dari orang lain tentang pengalamannya terhadap suatu produk.

\section{KESIMPULAN DAN SARAN}

Hasil penelitian menemukan bahwa pandemi Covid-19 sangatlah berdampak signifikan bagi pelaku usaha pertanian yang mengakibatkan menurunnya omset penjualan dan jumlah pengunjung sehingga berimbas pada karyawan. Akan tetapi, bagi pelaku usaha yang mampu melihat peluang dengan cepat di era pandemi ini, terutama dalam pemanfaatan platform digital sebagai media penjualan, maka akan dapat bertahan dengan baik. Di sisi lain, kendala yang dihadapi dapat diatasi dengan kesiapan dari pihak manajemen. Penelitian ini diharapkan dapat menjadi satu referensi yang membangun bagi pelaku usaha lainnya agar dapat terus bertahan dalam menjalankan usahanya di era pandemi
Covid-19. Bagi riset selanjutnya, dapat meneliti tentang persepsi pelaku usaha dari berbagai macam latar belakang usaha dalam melihat dampak positif maupun negatif dari adanya pandemi Covid-19.

\section{DAFTAR PUSTAKA}

Anwar, M. (2020). Dilema PHK dan Potong Gaji Pekerja di Tengah Covid-19. 'Adalah: Buletin Hukum Dan Keadlilan, 4(1), 173-178.

Artanti, A., \& Adinugraha, H. H. (2020). Strategi Pemasaran Word of Mouth pada Masa Pandemi Covid-19 (Studi pada Produk Home Industri Mie Eblek Desa Kasepuhan). Jurnal Manajemen Dan Ekonomi, 3(2), 224-235.

Awali, H., \& Rohmah, F. (2020). Urgensi Pemanfaatan E-Marketing pada Keberlangsungan UMKM di Kota Pekalongan di Tengah Dampak Covid-19. Jurnal Ekonomi Dan Bisnis Islam, 2(1), 1-14.

Hadiwardoyo, W. (2020). Kerugian Ekonomi Nasional Akibat Pandemi Covid-19. Journal of Business \& Entrepreneurship, 2(2), 83-92. https://doi.org/10.24853/baskara.2. 2.83-92

Hardilawati, W. L. (2020). Strategi Bertahan UMKM di Tengah Pandemi Covid-19. Jurnal Alkuntansi Dan Ekonomika, 10(1), 89-97.

Humas. (2020a). Cek Fakta: Tak Benar Presiden Joko Widodo Berlakukan Karantina Parsial. Retrieved from https://setkab.go.id/cek-fakta-takbenar-presiden-joko-widodoberlakukan-karantina-parsial/ (diakses 27 November 2020)

Humas. (2020b). Presiden Putuskan Pembatasan Sosial Berskala Besar Opsi Atasi Dampak Covid-19. 
Retrieved

https://setkab.go.id/presiden-

from

putuskan-pembatasan-sosial-

berskala-besar-opsi-atasi-dampakcovid-19/ (diakses 27 November 2020)

Miles, M. B., Huberman, M. ., \& Saldana, J. (2014). Qualitative Data Analysis: A Methods Sourcebook. Thousands Oak, California: Sage.

Pakpahan, A. K. (2020). Covid-19 dan Implikasi bagi Usaha Mikro, Kecil, dan Menengah. Jurnal Ilmiah Hubungan Internasional, 16(1), 59-64.
Sanjayawati, H. (2019). Perilaku Komplain, Penanganan Komplain dan Atribut Harga Pengaruhnya terhadap Kepuasan Pelanggan. Jurnal Bisnis Dan Manajemen, 6(2), 127-133.

Taufik, \& Ayuningtyas, E. A. (2020). Dampak Pandemi Covid-19 terhadap Bisnis dan Eksistensi Platform Online. Jurnal Pengembangan Wiraswasta, 22(01), 21-32.

Yunus, N. R., \& Rezki, A. (2020). Kebijakan Pemberlakuan Lockdown sebagai Antisipasi Penyebaran Corona Virus Covid19. Jurnal Sosial Dan Budaya Syar-I, 7(3), 227-238. 